\title{
A Belle Époque caipira: problematizações e oportunidades interpretativas da modernidade e urbanização no Mundo do Café (1852-1930) - a proposta do Cemumc ${ }^{1}$
}

José Evaldo de Mello Doin UNESP/Franca

Humberto Perinelli Neto CEUBM, FEF e UNESP/Franca

Rodrigo Ribeiro Paziani CBTA-Virtual/Rio Claro

Fábio Augusto Pacano Centro Universitário "Barão de Mauá" - Ribeirão Preto

\section{RESUMO}

Este artigo visa apontar a importância historiográfica de interpretar e compreender de maneira ampla e exaustiva as imagens, os discursos e demais vestígios que nos permitam ter acesso às sociabilidades, representações, projetos e práticas vivenciadas pelos habitantes das cidades do Brasil caipira, que apresentaram transformações geradas pela modernidade, no limiar do XX, em decorrência da nova dinâmica capitalista gerada pelos efeitos da expansão da economia cafeeira nessa região.

Palavras-chave: Brasil caipira; Modernidade; Economia cafeeira.

\section{ABSTRACT}

This article aims to point out the historiographic importance of interpreting and understanding in ample way the images, the speeches and other vestiges that allow the analysis the sociabilities, representations and practical projects lived by the inhabitants of the cities of 'Brazil caipira', which presented transformations generated by modernity, in the threshold of the $20^{\text {th }}$ century, in result of the new capitalist dynamics generated by the effect of the expansion of the coffee economy in that region. Keywords: 'Brazil caipira'; Modernity; Coffee economy. 
Na edição de 2 de maio de 1999, a Folha de S. Paulo publicava em seu caderno especial 'Ano 2000' um conjunto de matérias cujo título/tema era, ao mesmo tempo, inquietante e desafiador: “Qual será o futuro das cidades?”. Ao longo de todo o conjunto de artigos que constituía o referido caderno, o texto que dizia respeito ao crescimento das cidades médias chamava atenção, ocupando as folhas centrais dessa publicação. Baseado no estudo "Caracterização e tendências da rede urbana do Brasil”, os dados envolvendo as cidades médias traduziam um crescimento maior do que o ocorrido nas metrópoles, fenômeno especialmente registrado por parte das cidades localizadas no interior do estado de São Paulo. Tal mudança reporta o historiador para um outro momento.

Transformações desse porte merecem análise atenta. Porém, ao estudioso de história, o horizonte das dúvidas postas no presente, embora fundamentais, mostra-se mais amplo do que aparentemente possa vir a se configurar num primeiro instante. Devemos recordar, de acordo com Marc Bloch, ${ }^{2}$ que "nessa faculdade de apreensão do que é vivo é que reside, efectivamente, a qualidade fundamental do historiador", e, sendo assim, deve esse profissional efetuar suas investigações por meio de um "contacto perpétuo com o presente", pois, na verdade, prossegue Bloch,

o que o historiador deseja captar é exactamente uma mudança. Mas, no filme que observa, só está intacta a última película. Para reconstruir os vestígios apagados das restantes é forçoso, primeiro, desbobinar a película no sentido inverso das filmagens.

Dessa forma, atribuir importância ao atual fenômeno de crescimento das cidades médias brasileiras (em especial aquelas localizadas no interior do estado de São Paulo) é algo que deve, inegavelmente, ser realizado, dispensando-se, entretanto, o tratamento de ineditismo a esse processo. Isso porque o fenômeno urbano, responsável por transfigurar vilarejos em concentrações consideráveis de gentes e casas, vinha se acentuando no Brasil desde meados do Império. Concomitantemente à abolição efetiva do tráfico de escravos e graças a fatores vários - entre eles a liberação de capitais comprometidos com o comércio de cativos, a hegemonia alcançada pela produção cafeeira e a intensificação da imigração - inicia-se o desenvolvimento das cidades situadas no 'Brasil caipira', especialmente na porção interiorana do mapa paulista, mediante o que já foi chamado de 'modernização conservadora' e que deve, 
ao nosso ver, ser igualmente compreendido com base nos conceitos de capitalismo bucaneiro e de cordialidade.

Doravante, dada a importância que ocupam em nosso estudo, conceitos como 'modernização conservadora', 'capitalismo bucaneiro' e 'cordialidade' devem ser expostos mais detidamente. A idéia de modernização conservadora vincula-se ao modo como a costumeira e infeliz manutenção do poder das elites $^{3}$ se deu por meio da manipulação do desenvolvimento urbano e do desejo de experimentar os 'novos acessórios modernos' (urbanização, telefone e cinema, entre outros). Com relação ao 'capitalismo bucaneiro', ${ }^{4}$ trata-se do "casamento entre a capacidade de endividamento do Estado e a agilidade revelada pelos empreendedores de uma elite sem peias, nem mordaças morais..." e cujo processo histórico marcou a acumulação de riquezas no Brasil. Por fim, a idéia do 'homem cordial's implica atentar para as modalidades de convívio social que tanto marcaram o homem brasileiro, consistindo em relações de sociabilidade baseadas no domínio do privado e do íntimo e no desrespeito aos códigos de impessoalidade que regem as organizações burocráticas (como o Estado), bem como a posição e ou função exercidas pelo indivíduo.

Sob a inspiração dos escritos de Darcy Ribeiro, ${ }^{6}$ reconhecemos que esse Brasil caipira possuía certa configuração espacial/cultural, constituída em virtude de parte do território nacional ter sido formada por um processo histórico sensivelmente atrelado ao bandeirantismo e à mineração, eventos responsáveis pelo desenvolvimento de uma economia baseada num capitalismo mercantilista, que, mais tarde, se renderia à subsistência e ao pastoreio. Em decorrência disso, tal região seria caracterizada pela existência de sociedades especialmente marcadas:

1) pela miscigenação, originalmente promovida entre brancos e indígenas;

2) por um imaginário afeito ao enriquecimento fácil e rápido (crença no Eldorado); e

3) por uma disposição política fundada num profundo senso de autonomia e altivez.

Atentando para a atual divisão administrativa brasileira, tal região compreenderia os estados de São Paulo, Mato Grosso, Mato Grosso do Sul, Goiás e Tocantins, além de porções do Espírito Santo, do Rio de Janeiro e do Paraná.

A partir de meados do século XIX, por conta das plantações de café o Brasil caipira se transformaria num espaço capaz de coadunar tais caracterís- 
ticas com um profundo gosto pelo moderno e por toda a materialidade e simbolismo que o envolviam e que eram experienciados na Europa como marca de um novo tempo, ou melhor, daquilo que era tido como o 'melhor dos tempos': a Belle Époque. O termo revela que tais emblemas modernos possuíam relação estreita com a França, especialmente. É por conta disso, que durante o término do século XIX e princípio do século XX, muitos homens no interior paulista tinham seus sonhos povoados por desejos como o de viver um grande amor em Paris, desfrutar de seus cafés e cabarets, passear pelas suas ruas olhando as vitrines das butiques e admirando a luz elétrica, entre outras novidades técnicas e materiais. Seguindo as reflexões de Eric Hobsbawm, ${ }^{7}$ poderíamos dizer que tais personagens eram lançadas no "drama do progresso, a palavra chave da época: maciço, iluminado, seguro de si mesmo, satisfeito, mas acima de tudo, inevitável".

O tão ambicionado e desejado progresso envolvia a articulação de duas forças vitais e complementares por parte das elites locais: modernização e civilização. O conceito de modernização se baseia nos escritos de Marshal Ber$\operatorname{man}^{8}$ e é visto sob três ângulos diferenciados, embora complementares:

1) como um processo histórico de acumulação capitalista nas mãos de um pequeno grupo de fazendeiros de café;

2) como projeto de transformação material de costumes e da paisagem urbana das cidades; e

3) como processos sociais que impulsionaram ou obstacularizaram os investimentos urbanos das elites, bem como as estratégias de vivência dos populares.

Com relação ao conceito de 'civilização', concordamos com Jean Starobinski, ${ }^{9}$ quando afirma que existiram várias definições para esse termo, porém, a contar do momento em que "o valor dinâmico do sufixo de ação (ação) desapareceu, a palavra designa não mais um devir, mas um estado...”. Sendo assim, verificamos que civilização se torna léxico que:

carregado de sagrado demoniza seu antônimo. A palavra civilização, se já não designa um fato submetido ao julgamento, mas um valor incontestável, entra no arsenal verbal do louvor ou da acusação. Não se trata mais de avaliar os defeitos ou os méritos de civilização. Ela própria se torna o critério por excelência: julgar-se-á em nome da civilização. É preciso tomar seu partido, adotar sua causa. Ela se torna (o critério por excelência) motivo de exaltação para todos aqueles que respondem ao seu apelo; ou, inversamente, fundamenta uma condena- 
ção; tudo que não é civilização, tudo que lhe resiste, tudo que a ameaça, fará figura de monstro ou de mal absoluto. ${ }^{10}$

A Belle Époque caipira era constituída especialmente pela ação de uma elite desejosa de modernizar-se. Desobrigados de qualquer ética, derribavam as matas, levando destruição, morte e grilagem às terras férteis do sertão. Tal qual verdadeiros flibusteiros, adentravam a hinterlândia e agiam com violência, amparados na legitimidade de um discurso constituído a partir da significação social positiva atribuída ao moderno. Assim, o café seguia impávido, ladrilhando as localidades outrora semeadas e levando os trilhos e silvos das locomotivas em seu rastro. Rápido, então, lugarejos cresciam e tomavam forma de cidades, tornando-se, assim, centros bafejados pela força da grana que construía e destruía coisas belas, um verdadeiro admirável mundo, que mesclava sem possibilidades de separação o arcaico e o novo. Era nesse contexto que as ambivalências da própria modernidade se somavam às contradições de um país e de um povo forjado sob o sopro da bricolagem e da imposição do poder público.

\section{DESCRIÇÃO DO CENÁRIO E DAS POSSIBILIDADES INTERPRETATIVAS}

Por volta de 1852, vilazinhas e lugarejos localizados na porção interiorana do país eram tomados por uma avalanche de transformações. O que poucos anos antes eram apenas parcos aglomerado de casebres, anônimos, insignificantes, entregues à modorra sonolenta da rotina, num repente acordavam, tomados de pressa ingente para entrar no bonde da história e atingir as benesses do progresso, acordados que foram pelo aroma forte e instigante de uma bebida dadivosa como o café e atingidos pelo imaginário alimentado em torno do moderno. O rei café trazia consigo a electricidade, o automóvel e o telephone, os tecidos finos, o petit pavé, os bulevares, o calçamento das ruas e os palacetes, o aeroplano, o poudre de riz, o theatro e o cinematographo, entre outras 'novidades. ${ }^{11}$ Fantasmagorias pululavam parelhas com as fazendas que se formavam, com a circulação cada vez mais acelerada de capitais, braços (especialmente de imigrantes) e mercadorias, graças aos trilhos que avançavam por toda parte, criando verdadeiras bacias ferroviárias nos sertões paulistas. ${ }^{12}$

Contudo, a riqueza cafeeira precisou contar com uma ligação que tornasse possível uma ampla articulação dessa região com a Europa e os Estados Unidos. A referência ao ano de 1852, presente no título deste artigo, não é, portanto, aleatória. Foi nessa ocasião que surgiram as primeiras tentativas de fazer 
a ligação férrea entre o porto de Santos e o Planalto Piratiningano, para assim eliminar o gargalo que dificultava a exportação do café — projeto levado a cabo em decorrência de uma parceria entre investidores britânicos e um grupo local, encabeçado pelo barão de Mauá. ${ }^{13}$ Terminada em 1867, a The São Paulo Railway Company Limited foi a principal ferrovia do país, escoando a imensa produção cafeeira e, em movimento oposto, transportando os milhares de imigrantes do porto para as fazendas e as cidades, bem como tornando disponíveis aos moradores do rico interior desse estado os produtos e manufaturas importados e toda a marca de civilização e desenvolvimento que portavam. ${ }^{14}$

Os trilhos ferroviários articulavam de modo mais amplo também o Brasil caipira ao universo político brasileiro. O crescimento desabalado e sem medidas da riqueza no interior de São Paulo influía nas disputas veiculadas à conquista e ao exercício do poder público. Basta lembrar que essa região fez dois presidentes de estado: Altino Arantes e Washington Luís, tendo este último alcançado a suprema magistratura do país. Quinzinho da Cunha, chefe local do PRP, sogro de Altino Arantes, recebia constantemente altos mandatários, como Epitácio Pessoa e Wenceslau Brás. ${ }^{15}$ Figura também sempre presente nessa região era Antônio Prado, político igualmente de grande cepa, tendo em vista ocupar cargos como o de ministro e conselheiro imperial e prefeito da cidade de São Paulo. ${ }^{16}$ Outro nome de expressão era o de Francisco Schmidt, o maior proprietário de café do mundo no início do século XX, político atuante no município de Ribeirão Preto e conhecido como 'rei do café'.

Membros dessa elite política do Brasil caipira também lançavam mão do monopólio privado da violência. Contudo, vários são os casos impunemente 'contornados' e capazes de mostrar o ocultamento da barbárie com discursos e ações aparentemente civilizatórias. Entre eles destaca-se o famoso crime político ocorrido em Araraquara, denominado 'Linchaquara', ${ }^{17}$ e que envolveu duas poderosas famílias locais. Para que a população esquecesse o trágico episódio e as respectivas famílias continuassem a dominar o poder público municipal foi construída uma bela e ajardinada praça pública, exatamente no largo onde a chacina foi consumada. Um outro exemplo é o conhecido 'crime de Cravinhos, ${ }^{18}$ envolvendo a fazendeira ribeirão-pretana Iria Alves Ferreira, seus filhos e os capangas da própria família. Sob a marca da justiça e da racionalidade é que o assassinato de um dos capangas da família acabou por resultar na inocência de Iria, graças à intervenção, entre outros, do coronel Quinzinho da Cunha e de Washington Luís.

Assim, focalizar esses e tantos outros personagens ilustres da Belle Époque caipira mostra-se tarefa interessante para a compreensão da convivência 
de gestos e comportamentos arcaicos/bárbaros com aqueles considerados modernos/civilizados. Era nas câmaras municipais - e em outros espaços públicos, como teatros, hospitais e órgãos da imprensa - que os coronéis, majores, capitães e seu grupo de doutores comandavam a administração municipal, sempre a associando ao racionalismo modernizante mais recente. Entretanto, a velha arte da sociabilidade cordial e do mandonismo não era abandonada (como comprova o uso corrente de patentes), bem como não eram deixadas de lado as práticas de jagunçagem, presentes nas tocaias, no esquentamento de documentos de propriedade e na formação de condomínios da violência pelos agentes do Estado e pelos grupos privados detentores de poder nos municípios. Nesse sentido, cabe salientar o que Evaldo Doin afirma sobre o Estado brasileiro:

Sua face mais evidente, embora tenha sido sempre um aparato repressivo, forte e cruento, é a negação do monopólio da legitimação da violência no processo de concorrência com outros atores, antes pelo contrário, convive com manifestações perenes de controle e manipulação da violência por parte de grupamentos privados (capitães-do-mato, bugreiros, matadores, entradeiros, bandeirantes, sertanistas, feitores, capatazes, jagunços, cangaceiros, beatos, chefes de bando, provisórios, coronéis da Guarda Nacional, justiceiros, capangas etc.) e com eles se articula de forma suficientemente consistente, constituindo um condomínio, a ponto de se imporem de forma decisiva na arena do poder... ${ }^{19}$

É recorrente na historiografia do período a utilização da expressão oligarquia cafeeira para designar essa elite política e econômica. Essa identificação da elite do coffee business pressupõe a hegemonia de formações clânicoparentais e a constituição de uma estrutura social estamentalizada que permeia as esferas públicas (no sentido restrito do termo, ou seja, na estrutura administrativa e política do Estado e não na sua expressão midiática e na sociedade civil, sem, contudo, desprezá-las) e privadas constituintes da realidade nacional. ${ }^{20}$ Entretanto, outros grupos partilhavam das benesses do poder e das prebendas estamentais tão caras naqueles tempos: o anel de doutor, a patente da Guarda Nacional e ou um assento garantido no diretório municipal do PRP. Tal constatação faz pensar na constituição de uma plutocracia do dinheiro, isto é, um grupo mais amplo, constituído pelas grandes e tradicionais famílias, por jovens bacharéis e por arrivistas e industriais.

Com efeito, em uma abordagem mais ligeira não se pode negar a força econômica e política de grandes clãs familiares na coordenação das ações po- 
líticas tramadas no Brasil caipira. Como, por exemplo, não atentar para a influência dos Prado e dos Junqueira em praticamente toda região do nordeste paulista? Como deixar de notar a ingerência dos Faleiros e dos Jacintho em Franca, e dos Arruda Botelho em São Carlos e suas cercanias? Da mesma forma, como é possível não reconhecer a primazia dos Sampaio Vidal em Araraquara, dos Penteado no entorno de Mogi-Mirim e Mogi-Guaçu, dos Figueiredo e dos Pereira Barreto em Mococa e nas bandas mineiras adjacentes, entre outras famílias? O estudo dessas famílias é fundamental, dada a formação social brasileira, calcada no mandonismo, condição acentuada de modo especial, graças à estrutura burocrático-administrativa erigida durante a República Velha. ${ }^{21}$

Na compreensão da Belle Époque caipira, porém, insistimos no entendimento de que novos atores políticos ocuparam o espaço do poder público. A contrapelo da estrutura em parte herdada do Império, essa elite cafeeira era constituída também por homens formados em importantes faculdades do país, que assumiram os papéis de lideranças políticas locais tornando-se hábeis manejadores da 'coisa pública' e principais representantes das elites municipais. ${ }^{22}$ Tanto é assim que o baiano Joaquim Macedo Bittencourt exerceu grande influência política em Ribeirão Preto e foi seu alcaide por longos nove anos. Outro exemplo bastante ilustrativo é o de Washington Luís: pertencente a uma família fluminense arruinada, o jovem bacharel saiu da sua Macaé para tentar a vida na distante e diminuta Batatais, localidade onde iniciou uma vigorosa carreira política. Assinala-se ainda Silvestre de Lima, mineiro graduado em Farmácia no Rio de Janeiro, que em Barretos exerceu os cargos de vereador, presidente da Câmara Municipal, prefeito municipal, deputado estadual e coronel da Guarda Nacional.

Além dos bacharéis, aventureiros e arrivistas bem-sucedidos igualmente tinham acesso às escadarias do poder político. Explica-se assim o fato de imigrantes de boa estrela, como Francisco Schmidt e Artur Diederichsen em Ribeirão Preto, e Gaetano Petraglia em Franca, entre outros casos, serem engalanados, respectivamente, com as patentes de coronel, tenente-coronel e major-farmacêutico da Guarda Nacional. ${ }^{23}$ Da mesma forma, compreende-se o motivo que levava pioneiros da indústria a compartilharem o poder com as grandes e tradicionais famílias, muitos sendo incorporados a elas pelo casamento, caso dos 'condes' Siciliano e Francesco Matarazzo. Por fim, soma-se ainda a esse grupo uma fileira interminável de empreendedores, constituída, por exemplo, pelos Biagi, os Pignatari, os Innecchi, o pernambucano Pereira Ignácio, os Dedini, os 
Simonsen, os Gaffré e os Guinle, que viveram situação semelhante à dos pioneiros da indústria (incorporação à elite pelo casamento). ${ }^{24}$

Fato é que várias eram as personagens que se dirigiam para as terras do café em busca de oportunidades. Tudo em decorrência do comportamento cíclico do processo de expansão do café, que possibilitava o investimento de parte dos lucros na produção industrial, tornando-o um elemento indutor fundamental na criação de uma dinâmica favorável à modernização da economia. Continuando a tendência evidente no Império, ao longo da Primeira República eram suscitados investimentos (ainda que esparsos e embrionários) que se beneficiaram: do financiamento do excedente de lucros do complexo cafeeiro, do know-how e da mão-de-obra dos imigrantes, da crescente proteção alfandegária, da reserva de mercado criada pela Primeira Guerra Mundial, das reservas financeiras oriundas das manobras especulativas e de um mercado interno protegido pelos óbices criados pelo estado de beligerância mundial. ${ }^{25}$

Como já se sabia e se dizia com o cenho franzido e ar solene: 'o café dava para tudo'. O século XX se anunciava e o Brasil caipira se tornava palco destacado de várias mudanças. As ferrovias eram exemplos das oportunidades surgidas: Paulista, Mogiana, Araraquarense, Ituana e Sorocabana contabilizavam investimentos de cafeicultores e empreendiam uma nova dinâmica econômica às regiões em que atuavam. Além das ferrovias, indústrias diversas como as cervejarias Paulista e Antarctica em Ribeirão Preto, o Curtume Progresso em Franca, a Companhia Frigorífica Pastoril em Barretos, a Companhia Eletro-Metalúrgica também em Ribeirão Preto, o Engenho Central de Piracicaba, entre outros, alteravam o cenário das localidades interioranas. Diversos jornais, revistas, bem como estações de rádio, como é o caso da P.R.A.7 (Rádio Clube de Ribeirão Preto), ${ }^{26}$ entre outros modernos meios de comunicação, igualmente se tornavam corriqueiros no cotidiano dos moradores.

Essa riqueza gerada pelo café movia a busca por signos que a traduzissem. Várias eram as marcas de inspiração na utopia da Belle Époque, destacando-se, porém, o apreço pelos novos projetos arquitetônicos e urbanísticos. Com maior ou menor inventividade, não foi por acaso que a partir da implantação da lavoura cafeeira se fizeram presentes por boa parte do Brasil caipira as concepções do imperial prefeito de Napoleão III, o barão GeorgesEugène Haussmann. A haussmanização deve ser entendida como fenômeno urbano baseado nas reformas da capital francesa no século XIX, por conseguinte, envolvendo uma série de intervenções cirúrgicas - fruto da idéia de uma cidade doente, cuja solução requeria a demolição do traçado arcaico, o 
tratamento disciplinador dado aos edifícios e jardins públicos e a adoção de uma série de medidas higiênicas. ${ }^{27} \mathrm{O}$ emprego desse modelo urbanístico foi realizado, porém, conforme condições específicas de possibilidade existentes em cada uma das localidades.

Atuante também nas reformas do Rio de Janeiro ${ }^{28}$ e de São Paulo, ${ }^{29}$ o ideário desse modelo de cidade promovia o surgimento de uma vasta e multifacetada experiência urbanística, expressa e vivenciada nos traçados de Franca, Ribeirão Preto, Batatais, Araraquara, Piracicaba, São Carlos, Mococa, Bauru, Barretos e São José do Rio Preto, entre outras. Ao seu modo, cada localidade dialogava com um modelo aplicado em traçados arcaicos e marcado por um recorte ortogonal, grandes avenidas radiais, o indefectível quarteirão triangular, os boulevards arrematados por um ponto de mira qualquer e o tratamento escultórico e disciplinador dos edifícios. Assim, a racionalização ganhava importância e era expressa na constituição e legitimação de discursos administrativos, higienistas, urbanísticos e de engenharia associados ao ideal de regenerar..$^{30} \mathrm{Nada}$ diferente do que ocorria nas capitais, registra-se que tais discursos também serviam ao engendramento e à prática do poder pelas elites locais.

O mundo do coffee business se engalanava e se tornava rapidamente sofisticado. É curioso notar, por exemplo, que o Teatro Carlos Gomes, em Ribeirão Preto, se antecipou em 14 anos ao grande teatro da capital paulista, sendo igualmente concebido pelo Escritório Técnico Ramos de Azevedo e inaugurado com a ópera O guarani. ${ }^{31}$ Ainda no roldão da riqueza agrícola que se espalhava pelo interior paulista, cabe atentar para o fato de os teatros Santa Clara, de Franca, ${ }^{32}$ Variedades, de Mococa, ${ }^{33}$ e São Carlos, homônimo de sua cidade, terem sido inaugurados antes do princípio do século XX. Em todas essas edificações urbanas o ecletismo era o estilo reinante, expressão arquitetônica burguesa, típica do século XIX, e que primava pelo conforto, progresso, novidades e modismo das fachadas. ${ }^{34}$ Com relação ao Teatro São Carlos é significativo observar ter sido esse o local em que ocorreu pioneiramente a instalação de um cinematógrafo e, por conseguinte, foi exibida a primeira sessão de cinema no estado de São Paulo. ${ }^{35}$

Casas comerciais, bancárias e de prestação de serviços passavam a estampar títulos afrancesados ou que também indicavam o reconhecimento e a importância do progresso. Entretanto, a presença francesa não se dava apenas nos nomes das casas de comércio. O eco desse espirito ressoou fortemente no interior opulento, atuando na profunda modificação de hábitos e costumes, tornando-se símbolo do processo civilizatório, no sentido dado por Norbert 
Elias, ${ }^{36}$ ou seja, segundo um constante moldar e disciplinar de hábitos e comportamentos, que se estendem desde as pequenas regras de atitudes e etiquetas até a normatização e coerção que garantem o controle do Estado e do poder público municipal. O Código de Posturas de Batatais, por exemplo, primeiro do gênero e confeccionado por Washington Luís, representava o empenho das elites do interior em criar mecanismos de intervenção social, administrativa e urbana. Como afirmou o próprio Washington em sessão da Câmara de Batatais:

$\mathrm{Na}$ codificação das leis municipais dividi o meu trabalho em três partes. $\mathrm{Na}$ $11^{\underline{a}}$ parte tratei das Posturas Urbanas; aquellas que, na cidade e povoações, regulam a salubridade, tranqüilidade, segurança, commodidade e viação ... Na $2^{\underline{a}}$ parte occupei-me das Posturas Ruraes, aquellas que, na lavoura, são destinadas a mover a sua viação e segurança, seguindo o mesmo processo ... Na parte $3^{\underline{a}}$ consolidei as Posturas Especiais; aquellas que regulam as servidões, impostos e empregados, seguindo o mesmo processo da $1^{\underline{a}}$ parte... ${ }^{37}$

Naquele instante, entretanto, não eram apenas as cidades que mudavam, mas também os homens que nelas habitavam. O olhar ${ }^{38}$ tornava-se o sentido privilegiado desse 'feérico' baile de máscaras, em que se enrodilhavam e se embaraçavam homens sem raízes, prontos a inventar tradições ${ }^{39}$ e a forjar pátinas. 'Personas' ${ }^{40}$ de vários préstimos, papéis e cabedais surgiam em meio ao novo cenário urbano. Tinham lugar as crenças míticas nos valores burgueses do progresso, da opulência, da riqueza, do 'novo'. Por 'novo' entendia-se o que era construído no entorno da velocidade, das luzes, da assepsia, das sensualidades pós-barrocas das curvas e volutas do art-nouveau, dos florões e diamantes das frisas ornamentais das fachadas, da moda, do inebriante cheiro de gasolina, entre outros emblemas que eram construídos e destruídos rapidamente, num átimo, evidenciando uma realidade que se desmanchava no ar... ${ }^{41}$ De modo trôpego é que os homens buscavam posicionar-se diante dessa nova realidade.

Mas, se a elite cafeeira do interior paulista desejava construir as imagens modernas e civilizadas das suas cidades e de si mesma, fosse numa inauguração de obras públicas, fosse na publicação de revistas e almanaques, não menos intrigante era a participação dos chamados 'populares', ou, para usar uma expressão consagrada, dos 'pobres urbanos'. ${ }^{42}$ Em busca de eldoradas riquezas ou de simples oportunidades de empregos nas novas terras, tais personagens experienciavam a cidade, reinventando os espaços urbanos e as relações de 
sociabilidade desejadas. Várias fontes, caso especial dos jornais (inclusive os de curta duração) e documentos da Câmara, são importantes para o entendimento das formas de participação dessas camadas pobres da população, mesmo que excluídas, da Belle Époque caipira.

A movimentação política, a atuação profissional e a maneira como os pobres urbanos se faziam notar nas cidades analisadas é relevante. Estabelecendo novos serviços e atividades comerciais ou somando-se aos ofícios das nascentes indústrias, deixavam-se influenciar pelos movimentos anarquistas, anarco-sindicalistas e comunistas, que assustavam a elite, principalmente em tempos de carestia, realizando greves e motins operários. Muitos desses pobres, tão logo fixavam moradia nas áreas periféricas ou suburbanas, queixavam-se às autoridades municipais através de jornais ou requerimentos à Câmara, exigindo os melhoramentos urbanos introduzidos no centro, entre outras reivindicações.

Contudo, a ocorrência da Primeira Guerra Mundial reverteu abruptamente o quadro internacional dos fluxos econômicos e financeiros, atingindo letalmente as tenras e verdejantes economias latino-americanas. A busca desesperada do equilíbrio existente no período anterior às beligerâncias pelos combalidos países da Europa, por meio de radicais contenções de seus gastos e de suas importações, jogou no limbo os preços de nossas mercadorias. Após essa mega-guerra não seria uma mera ação contábil e monetária que restauraria a velha Europa, com todos os seus galardões, como a fonte emanadora de todo o processo civilizatório mundial. A Belle Époque com sua magia de luzes, mistura de estilos, ecleticamente sem estilo algum, passava a dividir espaço com um novo discurso sobre o novo. Da guerra nasceram outros modos, modas e mundo, por conseguinte, um novo discurso sobre o Brasil e seu povo.

Assiste-se, a partir de então, à ampliação da presença cultural e econômica dos Estados Unidos, ${ }^{43}$ fato que indicava a preservação do viciante gosto pelo moderno, porém, sob uma nova e diferente perspectiva, que o associava a novos emblemas. O mundo das imagens, dos cartazes imensos, dos sportsmen, do jazz-band, de Chicharrão, da velocidade, do automóvel, do aeroplano, do cinematographo, de Perola White e de Mutt \& Jeff, já coroava esse início dos frementes anos 20. A nova era surgia marcada por um sotaque de praticidade, ostentação, funcionalidade, crueldade darwinista e velocidade acentuada. Cada vez mais, a inspiração norte-americana se tornava um dado concreto à realidade dos homens e mulheres das terras do café, interpondose, assim, como algo a ser igualmente analisado pelos pesquisadores que se 
debruçam sobre a compreensão dos projetos modernizadores da Primeira República.

No decorrer da década de 1920, com a retomada da produção industrial por parte das nações cêntricas, mas em decorrência, principalmente, da alta competitividade dos produtos norte-americanos, ocorreu um verdadeiro derrame de mercadorias importadas nos portos e praças brasileiros, drenando as reservas de ouro amealhadas com sacrifício durante os anos de conflagração. ${ }^{44}$ A euforia de consumo no imediato período pós-beligerância esgotou rapidamente as reservas acumuladas durante o período de contenção forçada. A forte entrada de manufaturados norte-americanos, facilitada por uma agressiva política de crédito, por preços altamente competitivos e pela utilização inovadora e inusitada da propaganda superlotou o mercado brasileiro de bugigangas, de automóveis, de artigos domésticos e de gramofones e, com isso, provocou a aceleração da constituição da sociedade de massas. $\mathrm{O}$ viciante gosto pelo moderno era transubstanciado agora em novas formas.

Já chamada de 'fremente', a década de 1920 contemplava de modo mais definitivo o esboroamento dos alicerces dessa Belle Époque, posto que punha a pique a velha república oligárquica. A ditadura bernardista acelerava o desmonte da hegemonia paulista e mineira. O levante do Forte de Copacabana, a revolução de 1923 no Rio Grande do Sul, a revolução de 1924, bem como a Coluna Prestes indicavam a emergência de novos atores sociais e políticos. A Semana de Arte Moderna de 1922 apresentava um novo paradigma estético/artístico nacional, salientando a hibridez e a cultura popular. As organizações operárias também tomavam fôlego, graças à fundação do Partido Comunista. O perfil da elite rapidamente se modificava, haja vista que a industrialização se tornava assunto do dia, cada vez mais.

'Mudança', era esse o termo que conjugava a transição para a década de 1930: marco de um novo tempo e baliza finalizadora das pesquisas organizadas em torno da Belle Époque caipira. Um novo modelo de desenvolvimento passava a vigorar, junto com uma nova engenharia do poder e tantas outras questões que destoam da proposta deste estudo.

\section{PERSPECTIVAS EPISTEMOLÓGICAS E AÇÕES METODOLÓGICAS}

É sabido que com o surgimento da Escola dos Annales houve uma abertura de temas, abordagens e problemáticas. Todavia, tal abertura gerou por parte dos historiadores a necessidade de enfrentar as dificuldades impostas 
pela sua própria formação, desprovida do conhecimento de certas metodologias vinculadas, inicialmente, a outras disciplinas. Daí o fato de Lucien Feb$v^{4}{ }^{45}$ defender a formação de equipes multidisciplinares, que teriam como base a organização de um trabalho relacionado a uma determinada perspectiva temática e dotado de uma compreensão múltipla e social acerca do tempo. Nesses grupos temáticos poderia o historiador, nas palavras de Febvre, 46 "aproveitar o conselho dos outros” e, com isso, se desvencilhar do espírito de especialização, que impede uma compreensão mais apurada sobre os homens. Como afirma o próprio autor, no tom retórico que lhe era próprio:

se o historiador, em lugar de ser só ele a fazer vista; em primeiro lugar, construir os seus próprios utensílios; em seguida, fabricar as suas peças; e, finalmente reuni-las e fazê-las funcionar — se contentasse com o último papel? Se, tendo escolhido, por razões válidas, um assunto de estudos; tendo-o delimitado com cuidado; tendo marcado tudo o que antes de mais importava chegar a estabelecer (porque é preciso renunciar à idéia pueril de que tudo é igualmente interessante para todos) - organizasse as investigações de uma equipa composta ... reservando para si o papel difícil entre todos de estabelecer os questionários prévios; de relacionar as respostas fornecidas; de desprender delas os elementos de solução; de ordenar os inquéritos suplementares indispensáveis; sobretudo, de marcar as relações do problema posto com o conjunto dos problemas históricos do tempo que o formulou; se, tendo escolhido esta via longa, que afinal parecerá muito mais curta do que os velhos caminhos sinuosos de outrora, chegasse enfim a fazer da história uma ciência de 'problemas a pôr', senão a resolver sempre com a certeza e à primeira vez — creio que o seu papel estaria singularmente mais em evidência que o de um vago 'fabricante de livros pessoais. ${ }^{47}$

Marc Bloch, ${ }^{48}$ um outro ilustre fundador dos Annales, também frisou que a importância de uma transformação epistemológica do conhecimento histórico está relacionada ao desenvolvimento de equipes multidisciplinares: a melhor alternativa para tornar possível a preocupação com a compreensão mais ampla dos homens no tempo e, concomitantemente, evitar a busca falaciosa de uma metodologia específica para a história. Segundo ele, o historiador deve se ocupar de todos os aspectos vinculados à experiência dos homens no tempo, tarefa que o obriga a lidar com uma diversidade enorme de vestígios, que, por sua vez, requer uma gama de saberes e procedimentos próprios às "ciências vizinhas". Entretanto, por mais bem dotado que seja o investigador histórico, "tais conhecimentos encontrarão, sempre e geralmente muito 
cedo, os seus limites". Diante dessa situação, deve o historiador atinar para o fato de que:

Não há, então, outro remédio senão substituir a multiplicidade das competências reunidas num mesmo homem por uma aliança das técnicas praticadas por eruditos diferentes, não obstante tenderem todas elas para a elucidação de um único tema. Pressupõe este método a aceitação de um trabalho de equipa. Exige, igualmente a prévia definição, por um comum acordo, de alguns grandes problemas dominantes. São triunfos de que ainda nos encontramos muito longe. Contudo, não tenhamos dúvidas de que serão eles, em larga medida, que traçarão o futuro da nossa ciência. ${ }^{49}$

As pesquisas desenvolvidas em torno da Belle Époque caipira partilham das postulações expressas por Febvre e Bloch. Constituindo o Cemumc (Centro de Estudos da Modernidade e Urbanização do Mundo do Café), os autores desses trabalhos - historiadores, sociólogos, antropólogos, arquitetos, internacionalistas — apostam na idéia de que o 'contrabando do saber' entre áreas que têm como objetivo fundamental a compreensão do homem em diversos aspectos é a melhor alternativa para realização de estudos em torno de um processo tão rico e complexo. Partilhando de uma concepção temporal multidimensional, tais estudiosos visam compreender a experiência humana, por meio da interpretação de vestígios diversos, caso de traços e concepções arquitetônicas, rituais e celebrações que iluminam expressões arcaicas perante o moderno e ou vice-versa, códigos de sociabilidade tidos como civilizados, estratégias políticas oriundas das esferas pública e privada, acordos e tratados internacionais, entre outros.

À polifonia de vozes presentes nesse grupo juntam-se as possibilidades comparativas nas quais ele se ampara. Existem vários trabalhos sobre a economia cafeeira e seus efeitos - ferrovias, urbanização, costumes, traços arquitetônicos e urbanísticos. Todavia, está ainda por ser feito um trabalho coletivo que analise essas questões à luz da conjugação de várias ciências humanas e por meio de monografias locais. Sente-se também a ausência de análises comparativas entre cidades ligadas à economia cafeeira, mas que apresentam particularidades em relação à apropriação das oportunidades geradas:

1) em função da relação que possuem com outras economias — atreladas a ele, mas diferentes do café; 
2) em decorrência da ligação com uma determinada companhia ferroviária; ou, ainda,

3) por conta da atuação particular de homens que compunham as elites locais ou sobre elas possuíam influência.

Por fim, registra-se não haver estudos que articulem os efeitos da modernidade e os projetos e planos das companhias ferroviárias.

Tal preocupação remete nossa pesquisa ao que é chamado de micro-história. Num livro recente de entrevistas, um dos assuntos mais abordados por Maria Burke ${ }^{50}$ junto a proeminentes historiadores diz respeito aos limites e possibilidades dessa forma de abordagem. Natalie Davis destacou a sua importância e assinalou as dificuldades existentes, tendo em vista a pesquisa de detalhes e evidências envolvidas e que lhe emprestam a ambição de uma histoire total. Keith Thomas salientou que deve ser uma das muitas formas de se produzir o conhecimento histórico e não a única, e frisou que exige muito do estudioso (que depara com dificuldades quanto às fontes) e que sua validade está circunscrita a determinados assuntos e certos personagens. Já Jack Goody pontuou a necessidade de reconhecermos outras formas de análise histórica e criticou a tendência de os trabalhos de micro-história se deterem apenas na interpretação da reação dos observadores e não traçarem o entendimento das próprias pequenas comunidades.

Divergências à parte, é possível notar que a micro-história faz parte da pauta dos estudiosos no momento. A importância desses estudos teve início nos anos 60 e 70, ${ }^{51}$ quando os historiadores passaram a abandonar o emprego dos "métodos quantitativos, interessados na vida de milhões de pessoas e concentrados na análise das tendências gerais" e, seguindo os antropólogos sociais, investiram em análises mais recortadas, que possibilitassem perceber a "vida humana mais de perto". ${ }^{52}$ Nesse período, o sucesso e as virtudes constatadas em obras como Montaillou (1975) e Os queijos e os vermes (1976) produzidas por Emanuel Le Roy Ladurie e Carlo Ginzburg, respectivamente — contribuíram para a divulgação dessa abordagem. Nos anos 80, Natalie Zemon Davis também se tornaria uma referência nessa forma de trabalho, principalmente em decorrência da publicação de sua obra O retorno de Martin Guerre, adaptada para o cinema numa versão que contava com a participação do ator Gérard Depardieu.

Próxima da proposta principal dos Annales, a micro-história pode ser inserida naquilo que François Dosse ${ }^{53}$ denominou 'pluralidade dos modelos' e 'guinada interpretativa'. Conforme destaca Ronaldo Vainfas, ${ }^{54}$ verifica-se em 
trabalhos como os de Ginzburg, Davis e Ladurieu a compreensão do tempo a contar de uma nova perspectiva, ligada ao vivido e não ao estrutural, capaz de articular o individual ao coletivo, própria em associar a história ao plausível e não ao pretensioso, além de configurar um discurso politicamente mais atuante, haja vista que vislumbra a ação e a reflexão dos sujeitos diante de seus contextos históricos. Assim, nesses trabalhos ocorre a compreensão dos elementos constituintes de uma dada realidade (econômicos, ideológicos, políticos e sociais), sem o ônus de apagar a consciência e a prática dos sujeitos históricos, mesmo que estejam fundamentalmente associados aos 'limites do possível'.

Segundo Janaína Amado, ${ }^{55} \mathrm{o}$ crescimento das análises locais e regionais na historiografia brasileira produzida nas últimas décadas se deve, principalmente, à multiplicação dos cursos de pós-graduação pelo país. Segundo a referida historiadora são de extrema importância as vantagens que tais abordagens possuem, entre as quais destaca três pontos em especial. Inicialmente, permitem elas o enriquecimento das análises nacionais, uma vez que tornam possível o enfrentamento de "todas as questões fundamentais da História a partir de um ângulo de visão que faz aflorar o específico, o próprio, o particular". Além disso, apresentam os agentes históricos e seu cotidiano, sua realidade, com mais riqueza de detalhes e, por conseguinte, assinalam melhor "a ligação do indivíduo e a sociedade”. Por fim, tornam visível a riqueza envolvendo os processos históricos, chamando atenção para a necessidade de se examinar as teorias globais sob a luz das especificidades constatadas.

Dedicando-se a entender a guinada promovida pelos historiadores que se uniram em torno das abordagens micro-sociológicas é que Paul Rosental ${ }^{56}$ assinalou alguns dos princípios antropológicos que se fizeram influentes, por conta das reflexões buscadas nos pressupostos teórico-metodológicos desenvolvidos por Fredrin Barth. Uma das premissas incorporadas é a de que a dinâmica social é mais bem percebida segundo as teorias dos jogos, isto é, conforme a idéia de que os atores sociais estão em interação, efetuam escolhas, as quais manifestam em certas ações, embora não sejam livres, já que estão vinculados a determinados processos e causas, responsáveis por lhes impor limites (conscientes ou não). Desse prisma surge a noção de que a vida social é elaborada dentro de uma "diversidade arranjada de práticas", cabendo ao historiador reconstituir essa diversidade para se aproximar do real vivido.

Conforme Pierre Levi ${ }^{57}$ e Jacques Revel, ${ }^{58}$ o objetivo daquele que se dedica à micro-história é, justamente, o de enfrentar as limitações surgidas das interpretações que atribuíram proeminência a indicadores simples em dema- 
sia, por conta da busca de regularidade. Em vez disso, operando no 'micro', deve o historiador expressar a complexidade da realidade, desenvolvendo uma narrativa composta por uma conceituação mais fluida, uma classificação menos prejudicial do que constitui o social e o cultural e um arcabouço de análise que rejeita simplificações, hipóteses dualistas, polarizações, tipologias rígidas e a busca de características típicas. Com isso, tanto se estuda o social como um conjunto investido de propriedades inerentes, de inter-relacionamentos e deslocamentos existentes entre configurações em adaptação, como se salienta o papel do indivíduo na intervenção de uma realidade que parecia ter surgido por circunstância ou necessidade.

Como bem salienta Peter Burke, ${ }^{59}$ mais comum entre sociólogos e antropólogos, o estudo de "espaços mais precisos", como os de uma aldeia, vila ou cidade, vem ganhando força entre os historiadores. Com esses estudos surge a necessidade de compreender as comunidades humanas existentes nesses locais, de modo que não se trate qualquer um deles "como se fosse uma ilha" nem se "ignore a relação existente entre a micro-análise e a macro-análise". Daí atrelarmos o estudo das transformações promovidas pela riqueza gerada pelo café ao contexto vivido pelo estado de São Paulo, o Brasil e o mundo, salientando que tal articulação encontrava facilidades em sua concretização, tendo em vista o café ser um produto-mundo: plantado num local, articulavase aos projetos de uma elite encastelada nas esferas estaduais e federais e era consumido especialmente nos Estados Unidos e na Europa, de onde surgiam os projetos modernizadores.

Partindo de uma base filosófica que aceita a idéia de que "a realidade é social ou culturalmente constituída”, os pesquisadores do Cemumc se dedicaram ao estudo de uma maior variedade de atividades humanas e, por conseguinte, buscaram mais evidências dessas atividades ${ }^{60}$ Tal como Marc Bloch,${ }^{61}$ fugimos assim da falaciosa crença de que a cada problema histórico corresponde um tipo único de documentos, reconhecendo, em vez disso, que "quanto mais a investigação procura alcançar os fatos profundos, menos lhe é permitido esperar outra luz que não seja a dos raios convergentes de testemunhos sobremaneira diversos na sua natureza". Desta feita, acreditamos que "é quase infinita a diversidade dos testemunhos históricos", devendo o pesquisador atentar para "tudo o que o homem diz ou escreve, tudo em que toca, pode e deve informar a seu respeito". Todos os vestígios são válidos e preciosos.

Eleger o estudo das transformações materiais, sociais e simbólicas que vão se fazendo presentes em várias cidades do Brasil caipira significou também optar por um determinado caminho teórico e metodológico. Cientes de 
que nas últimas décadas ocorreu um redimensionamento no campo historiográfico, incluímo-nos numa das vertentes do que Lynn Hunt ${ }^{62}$ denominou "nova história cultural": aquela tributária da antropologia, disciplina cujo instrumental analítico é utilizado para enriquecer a abordagem histórica. Contudo, prova do pressuposto de que "a micro-história é essencialmente uma prática historiográfica em que suas referências teóricas [e metodológicas] são variadas e, em certo sentido, ecléticas", lançamos mão também das contribuições de estudiosos ligados a outras "ciências vizinhas", tais como a antropologia, a sociologia, a economia, a geografia, a arquitetura, o urbanismo e a lingüística. ${ }^{63}$

\section{EIXOS E VEREDAS CONCEITUAIS}

A contar do momento em que foram incluídas no jogo das trocas mercantis promovidas pela economia cafeeira, é notório que características relacionadas à modernidade passaram a fazer parte de todo um conjunto de cidades do interior de São Paulo. Novidades tecnológicas, comportamentos, símbolos e ritos diferentes, bem como novos códigos de sociabilidade e relações de poder foram instaurados. Dessa forma, levar em conta a compreensão da modernidade é tarefa à prova em nosso estudo e configura o primeiro eixo conceitual. Todavia, evitando a simples adoção de modelos teóricos, a reificação da modernidade e o estrangulamento das especificidades locais, e promovendo, assim, a interpretação da 'tensão' entre o que é herdado e o que é modificado é que empreendemos uma interpretação da modernidade em conformidade com os poderes e saberes que definem e constituem os espaços locais.

Segundo essa perspectiva, tratou-se de entender a modernidade de acordo com as condições de possibilidade presentes em cada lugar. Tal alternativa pareceu ser mais interessante, tendo em vista que oportuniza o entendimento da modernidade segundo a plasticidade que a envolve e, por conseguinte, a especificidade que adquire em cada uma das configurações sociais nas quais se faz atuante. Com isso, tanto as transformações socioeconômicas (caso do crescimento urbano, da industrialização da produção e dos sistemas de comunicação de massa, entre outros) quanto as apreensões (vinculadas à estética, à ciência e à moralidade) que buscaram refletir e traduzir as incertezas e as dúvidas advindas desse processo histórico foram relativizadas ou, melhor dizendo, foram particularizadas. A modernidade é assim tomada como um tecido temporal em que seus 'desvios' não são negligenciados. 
Cada qual a seu modo, vários são os estudiosos que adotam essa perspectiva. Georges Balandier ${ }^{64}$ defende a idéia de que "a modernidade pode ser qualificada de tradição do novo", posto que se configura numa espécie de movimento de destruição e desestruturação, constituinte do inédito, do desconhecido, sem desprezar o já existente e o arcaico. Anthony Giddens ${ }^{65}$ afirma que nas combinações entre passado e presente é que se formam as articulações que tornam a compreensão da modernidade uma tarefa difícil. David Harvey, ${ }^{66}$ por sua vez, salienta que associada ao universalismo, o internacionalismo e o globalismo, na verdade a modernidade nunca se desprendeu totalmente do "paroquialismo etnocêntrico". Perry Anderson ${ }^{67}$ também admite que a modernidade foi efetiva e integral em países que permitiram a ocorrência do que denomina "intersecção de diferentes temporalidades".

Ao propormos a vinculação dessas pesquisas às cidades e aos espaços urbanos constituintes do Brasil caipira, levamos em conta lições parecidas àquelas considerações em torno da modernidade, ou seja, atentamos para a plasticidade e a especificidade que envolve. Assim, ressalta-se que ao estudar as cidades é necessário evitar a simples assimilação de modelos teóricos, a reificação do urbano e a desconsideração das configurações locais. A este respeito, Ronald Raminelli ${ }^{68}$ destaca que os estudos de história vêm crescendo nos últimos anos, mas que "a historiografia caiu numa armadilha teórica, repetindo os mesmos resultados obtidos por historiadores preocupados com outras realidades". A pesquisa desse segundo eixo conceitual busca fugir de qualquer enquadramento conceitual e, por conseguinte, de uma marginalização da base empírica do trabalho, posto o risco de se compor uma narrativa em que se cruzam:

Transeuntes que não se conhecem e se ignoram, estrangeiros, marginais, conspiradores, dândis, colecionadores, assassinos, panoramas, galerias, vitrinas, manequins, modernidade e ruínas da modernidade, shopping centers e elevados. Um murmúrio em que as palavras flâneur e flânerie são usadas como inesperados sinônimos de praticamente qualquer movimento que tenha lugar nos espaços públicos. Fala-se da flânerie em cidades onde, por definição, seria impossível a existência do flâneur. O simples passeante vespertino de uma praça interiorana ou de um calçadão que não tem mais do que duas quadras tornou-se personagem de um romance filosófico urbano, esboçado conforme a teoria benjaminiana sobre a modernidade no século XIX ou sobre as ruínas do capitalismo na vitrina de suas mercadorias. ${ }^{69}$ 
O estrangulamento das interpretações das experiências urbanas por conta da reprodução epistemológica aniquila um dos aspectos mais essenciais dos estudos sobre cidades: as múltiplas possibilidades de se efetuar análises que atentem, ao mesmo tempo, ao que é comum e ao que é específico. Tal característica é que provoca num escritor como Ítalo Calvino ${ }^{70}$ a defesa da idéia de que a cidade é uma realidade múltipla, apreendida segundo perspectivas várias. Sendo assim, pode ser percebida, entendida e interpretada como um fenômeno mental, físico, social, econômico, instâncias de investigação em muitas ocasiões conciliáveis e cuja escolha está baseada em olhares distintos que lhe são dirigidos, como o do historiador, do geógrafo, do arquiteto, do filósofo, do economista, do antropólogo, do cientista político e do literato. ${ }^{71}$ Néstor Canclini resume essas múltiplas apreensões lançando mão da seguinte metáfora:

O antropólogo chega à cidade a pé, o sociólogo de carro e pela pista principal, o comunicólogo de avião. Cada um registra o que pode, constrói uma visão diferente e, portanto, parcial. Há uma quarta perspectiva, a do historiador, que não se adquire entrando, mas saindo da cidade, partindo de seu centro antigo em direção aos seus limites contemporâneos. Mas o centro da cidade atual já não está no passado. ${ }^{72}$

Um outro eixo temático que deve ser considerado oportuno para realização das pesquisas é o que envolve as relações internacionais, entendidas em nosso estudo como as aproximações bilaterais e ou multilaterais entre países, por meios que extrapolam o simples jogo de chancelarias ou os acordos financeiros. Sendo assim, faz parte desse foco tudo aquilo que vincula o estreitamento das distâncias e tempos caracterizantes de diversos países e é capaz de inserir o Brasil numa aldeia global. Isto porque o coffee business intensificava o processo de mundialização e, portanto, se constituía num dos principais responsáveis pela articulação do país nas relações internacionais, por meio da riqueza, das necessidades, das oportunidades e/ou dos gostos das personagens diretamente ou indiretamente vinculadas a tal economia.

As relações internacionais que marcam o Brasil ao longo do período 18521930 envolvem, invariavelmente, a economia cafeeira. Isto porque os empréstimos externos e os investimentos diretos estrangeiros cumpriam, num nível mais complexo, o papel de modernizar internamente a economia brasileira, impulsionar a sua urbanização e desenvolver uma nova concepção cultural, que o condicionava a agir num cenário de negociações. ${ }^{73}$ As políticas de valo- 
rização do café são indicativas dessa postura, posto se tratarem de manipulações dos estoques desse produto nos principais mercados internacionais, conforme uma política especulativa, que era velha conhecida dos finórios comissários, políticos e fazendeiros, desde os antanhos do Império. ${ }^{74}$

O café era um produto-mundo que, por isso mesmo, articulava espaços e tempos humanos distantes, materializados e consubstancializados em sociabilidades, culturas, regimes políticos, enfim, civilizações díspares. ${ }^{75} \mathrm{~A}$ economia cafeeira envolvia o domínio financeiro, da comercialização, da importação de insumos e máquinas, da propaganda do produto nas principais praças, dos armazéns espalhados pela Europa e nos Estados Unidos. Como se não bastasse, movia ainda a importação de mão-de-obra, as negociações comerciais perenes e cotidianas, o desenvolvimento de um sistema de escoamento ferroviário, a modernização portuária e a implantação de técnicas modernizadoras de produção.

Podem ainda ser considerados assuntos do campo das relações internacionais a importação e transmigração de hábitos, modas, estilos arquitetônicos e entretenimentos. Tais ações eram derivadas, especialmente, da experiência imaginária francesa, mas repercutiam nas cidades do Brasil caipira graças à participação ativa de imigrantes italianos, espanhóis, portugueses e síriolibaneses, especialmente nas atividades de comércio, indústria, lazeres e importação. ${ }^{76}$ Nesse caso, fazem parte também das análises vinculadas a este eixo a repercussão do tratamento dispensado aos imigrantes europeus em terras brasileiras, as estratégias e os procedimentos desenvolvidos e desempenhados pelos agentes migratórios, entre outras questões dessa natureza.

Prosseguindo, ao analisarmos o impacto da riqueza gerada pela economia cafeeira em um conjunto de cidades torna-se imprescindível interpretar a valorização da memória num contexto marcado pelo advento do efêmero. A indicação deste quarto eixo temático se faz necessária, tendo em vista o fato de a modernidade ser marcada pelo afluxo de uma série de transformações radicais, situação que nos impele à avaliação das estratégias pelas quais os próprios atores sociais, os representantes do poder público ou os demais grupos vinculados aos espaços em estudo se posicionaram diante da possibilidade de perda do 'mundo conhecido'. O estudo da memória envolve a compreensão de celebrações do passado, certas tradições, determinadas lembranças, enfim, elaborações/criações/invenções de diversos artefatos culturais que foram, em geral, responsáveis por criar um vínculo simbólico entre passado e presente.

A importância da abordagem da memória é atestada, posto que, ao longo da segunda metade do século XX, o seu uso constituiu um 'campo de batalhas' 
que abrigou velada disputa pela atribuição de significados à experiência de um grupo social, dados os estudos que apontavam para o fato de o discurso não ser neutro e, ao contrário disso, marcado por certa ideologia/imaginário. Diante de tais conclusões, passou-se a defender que a memória está, portanto, revestida de importância fundamental na construção da identidade social, tanto do grupo social investigado quanto daquele que, ao narrar, recorda aspectos do passado. ${ }^{77}$ A experiência é a própria memória, o que coloca o historiador diante do maior dilema das ciências humanas: a indissociável identidade entre sujeito e objeto, pois, de acordo com Thompson:

historiadores também se ocupam, em sua prática cotidiana, da formação da consciência social e de suas tensões ... Propõem novos problemas e, acima de tudo, dão origem continuadamente à experiência — uma categoria que, por mais imperfeita que seja, é indispensável ao historiador, já que compreende a resposta mental e emocional, seja de um indivíduo ou de um grupo social. ${ }^{78}$

Não obstante, muitos são os caminhos existentes acerca do debate sobre a memória para investigação dos atores sociais que compunham a Belle Époque caipira. Para Maurice Halbwachs, ${ }^{79}$ ela deve ser entendida como um conjunto de representações coletivas. Já Frederic Bartlett ${ }^{80}$ argumenta que a memória - percepção, reconhecimento e reminiscência - é entendida como um processo de interação entre indivíduos e entre estes e seu meio. Michel Pollak, ${ }^{81}$ por sua vez, pensa-a a "como um fenômeno coletivo e social", ou seja, como um fenômeno construído coletivamente e submetido a flutuações e mudanças constantes. Para Walter Benjamin ${ }^{82}$ a memória se reveste de certa 'aura', que nos possibilita ultrapassar o necessário, porém insuficiente, conhecimento factual, permitindo-nos analisar os nexos entre processos sociais já objetivados e processos emergentes.

Por fim, destaca-se o quinto e último eixo temático: o cotidiano. A partir da década de 1970 é que os historiadores se preocuparam mais efetivamente com uma abordagem que levasse em conta a articulação entre economia, cotidiano e sociedade. ${ }^{83}$ Foi a partir de Fernand Braudel ${ }^{84}$ que a análise do cotidiano ganhou consistência, tendo em vista que ele foi articulado a uma dimensão histórica mais ampla, em que o habitual é verificado sob as forças ditadas pelas realidades econômicas e sociais, os valores culturais e os significados simbólicos, bem como as decisões políticas de grupos e instituições. $\mathrm{Na}$ investigação dessa tensão entre os tempos herdados e a serem construídos, três estudiosos se destacam: Michel de Certeau, ${ }^{85}$ Michel Maffesoli ${ }^{86}$ e Pierre Bourdieu. ${ }^{87}$ Em comum, o fato de conjugarem o agir humano com as estru- 
turas que moldam seu entorno: o que significa, em nosso caso, espreitar a articulação entre o caipira e a Belle Époque.

A dedicação a esse tema é fundamental, pois é na observação do cotidiano que se torna possível a interpretação do conjunto de vivências dos moradores das cidades do Brasil caipira diante dos efeitos da modernidade. Podemos compreender tais vivências nas atitudes políticas das elites e nas interpelações populares; na posição de homens e mulheres frente a uma economia de consumo, de modismos e de uma disciplina dos gestos e atos; na fruição de uma nova definição espacial e de meios de comunicação nunca vistos. Em todas essas análises, partimos da consideração das sociabilidades e dos valores que configuravam o modus vivendi desses homens e mulheres num período anterior e o modo como definiram a leitura e a apropriação daquilo que constituía o novo. Agindo dessa forma, insistimos na difícil tarefa de compreender a experiência surgida de confrontos de modos de ver e viver a realidade, por parte dos habitantes dos múltiplos espaços urbanos que compunham a região estudada.

Dito tudo isso, não é exagero, talvez, afirmar que o estudo da Belle Époque caipira traz consigo possibilidades inovadoras, no que se refere ao entendimento da modernidade. Por meio de um conjunto de pesquisas cuja base empírica está associada a diversas localidades - expediente associado ao exercício de micro-história - empreende-se a tentativa de captar o drama humano provocado pela modernização e a percepção de seus efeitos na atenção para com as ações dos personagens, fazendo assim fluir as particularidades. Além disso, por meio das especificidades levantadas junto aos viventes dessas localidades é que se torna permitido um estudo comparativo do impacto da economia cafeeira e de tudo o que esteve a ela associado no Brasil, durante fins do século XIX e primeiras décadas do século XX. Complexidade e particularidade: um interessante norte a seguir e um projeto historiográfico a marcar o ofício de alguns estudiosos.

\section{NOTAS}

${ }^{1}$ Este texto baseia-se nos escritos que compõem o Projeto Temático "A Belle Époque caipira: modernidade e urbanização no Mundo do Café (1852/1930)", sob coordenação do prof. dr. José Evaldo de Mello Doin e do qual fazem parte vários pesquisadores, entre os quais os outros três autores deste artigo.

${ }^{2}$ BLOCH, M. Introdução à história. (Trad. Maria Manuel e Rui Grácio). 6.ed. Lisboa: Europa América, 1941. p.43-5.

${ }^{3}$ Vários trabalhos ilustram tal conceito, entre os quais: SEVCENKO, N. Introdução: o pre- 
lúdio republicano, astúcias da ordem e ilusões do progresso. In: SEVCENKO, N. (Coord.) História da vida privada no Brasil: República: da Belle Époque à Era do Rádio. 4.reimpr. São Paulo: Companhia das Letras, 2001. v.3, p.7-48.

${ }^{4}$ DOIN, J. E. M. Capitalismo bucaneiro: dívida externa, materialidade e cultura na saga do café (1889-1930). Tese (Livre docência em História) — Faculdade de História, Direito e Serviço Social, Unesp, Franca, 2001. 2v. p.6.

${ }^{5}$ HOLANDA, S. B. Raízes do Brasil. 8.reimpr. São Paulo: Companhia das Letras, 1995.

${ }^{6}$ RIBEIRO, D. O povo brasileiro: formação e sentido do Brasil. 2.ed. São Paulo: Companhia das Letras, 2004. p.364-407.

${ }^{7}$ HOBSBAWM, E. A era do capital — 1848/1875. (Trad. Luciano Costa Neto). Rio de Janeiro: Paz e Terra, 1977. p.24.

${ }^{8}$ BERMAN, M. Tudo que é sólido desmancha no ar: a aventura da modernidade. (Trad. Carlos Felipe Moisés e Ana Maria L. Ioriatti). 15.reimpr. São Paulo: Companhia das Letras, 1997. p.16.

'STAROBINSKI, J. As máscaras da civilização: ensaios. (Trad. Maria Lúcia Machado). São Paulo: Companhia das Letras, 2001. p.32.

${ }^{10}$ Ibidem.

${ }^{11}$ Uma visão panorâmica do processo de modernização das cidades do Mundo do Café pode ser encontrada em: DOIN, J. E. M. A régua e o compasso nas terras do café: a haussmanização das cidades do interior paulista na República Velha. In: ENCONTRO REGIONAL DE HISTÓRIA, XI, “História e Exclusão Social”. Anais... Uberlândia: Universidade Federal de Uberlândia, Centro de Ciências Humanas e Artes, Anpuh/MG, 27 a 31.07.1998. Comentários específicos sobre algumas das novidades modernas nessas cidades são discutidos em: DOIN, J. E. M. Entre gênero \& arte: a mão feminina na urdidura do modernismo. Revista Caderno espaço feminino, Uberlândia: Edufu, v.11, n.14, p.59-87, 2004; DOIN, J. E. M. Olhar, desejo e paixão: lazeres e prazeres nas terras do café. ArtCultura, Uberlândia, v.1, p.40-53, 2000.

${ }^{12}$ MATOS, O. N. Café e ferrovias: a evolução ferroviária de São Paulo e o desenvolvimento da cultura cafeeira. 2.ed. São Paulo: Alfa-Ômega, 1974; SAES, F. A. M. As ferrovias de São Paulo: 1870-1940. São Paulo: Hucitec, 1978; QUEIROZ, P. R. C. Uma ferrovia entre dois mundos: a E. F. Noroeste do Brasil na primeira metade do século XX. Bauru: Edusc/UFMS, 2004.

${ }^{13}$ Tal parceria faz considerar correta a afirmação de que a consolidação da economia agroexportadora "não se limita ao circuito do mercado internacional, mas penetra na sociedade, solidarizando interesses de grupos e classes internos e externos e gerando pactos políticos entre eles que desembocam no interior do Estado". CARDOSO, F. H. As idéias e seu lugar: ensaios sobre as teorias do desenvolvimento. Petrópolis: Vozes; São Paulo: Cebrap, 1980. p.10-1.

${ }^{14}$ GITAHY, M. L. C. Ventos do mar. São Paulo: Unesp/Prefeitura Municipal de Santos, 1992. 
${ }^{15}$ CUELLO, J. P. Poder na Belle Époque caipira: Quinzinho da Cunha - o Godfather do PRP. Trabalho de Conclusão de Curso (Graduação em História) - Universidade Estadual Paulista Júlio de Mesquita Filho, Franca, 2003.

${ }^{16}$ PERINELli NETO, H. Pelas ruas da 'Chicago Brasileira': modernidade, pecuária e complexo cafeeiro - Barretos (1852/1929). Projeto (Doutorado em História) - FHDSS, Unesp, Franca, 2005.

${ }_{17}$ TELAROLLI, R. Os sucessos de Araraquara: estudo em torno de um caso de 'coronelismo’ em fins do século XIX. Dissertação (Mestrado em História) — FFLCH, USP, São Paulo, 1975.

${ }^{18}$ JORGE, J. O crime de Cravinhos: oligarquia e sociedade em São Paulo (1920-24). Dissertação (Mestrado em História) — FFLCH/USP, São Paulo, 1998.

${ }^{19}$ DOIN, J. E. M., 2001, cit., p.40.

${ }^{20}$ Essa forma de abordagem pode ser conferida em: CARONE, E. A República Velha: instituições e classes sociais. 4.ed. Rio de Janeiro/São Paulo: Difel, 1978 (Corpo e Alma do Brasil); CARONE, E. A Primeira República: texto e contexto (1889-1930). Rio de Janeiro/São Paulo: Difel, 1976 (Corpo e Alma do Brasil).

${ }^{21}$ Sobre o mandonismo e o coronelismo na República Velha, sempre recorrer aos clássicos: QUEIROZ, M. I. P. Mandonismo local na vida política brasileira e outros ensaios. São Paulo: Alfa Ômega, 1976; LEAL, V. N. Coronelismo, enxada e voto: o município e o regime representativo no Brasil. São Paulo: Alfa Ômega, 1978; FAORO, R. Os donos do poder: formação do patronato político brasileiro. 2.ed., revista e aumentada. Porto Alegre: Globo; São Paulo: Edusp, 1975. 2v.

${ }^{22}$ Os exemplos de Ribeirão Preto, Batatais e Barretos podem ser conferidos, respectivamente, em: PAZIANI, R. R. Construindo a 'Petit Paris': Joaquim Macedo Bittencourt e a Belle Époque em Ribeirão Preto (1911-1920). Tese (Doutorado em História) - FHDSS, Unesp, Franca, 2004; PEREIRA, R. M. O municipalismo de Washington Luís em sua atuação em Batatais (1893-1900): aspectos da modernização urbana do interior paulista na República Velha. Dissertação (Mestrado em História) — FHDSS, Unesp, Franca, 1998; PERINELLI NETO, H. Pelas ruas da 'Chicago Brasileira', cit.

${ }^{23}$ Verificar: WALKER, T. W; BARBOSA, A. S. Dos coronéis à metrópole: fios e tramas da sociedade e da política em Ribeirão Preto no século XX. Ribeirão Preto: Palavra Mágica, 2000; CASALECCHI, J. Ê. O Partido Republicano Paulista: política e poder (1889-1926). São Paulo: Brasiliense, 1987; CHIAVENATO, J. J. Coronéis e carcamanos. São Paulo: Global, 1982.

${ }^{24}$ GRIEG, M. D. Café: histórico, negócios e elite. São Paulo: Olho d’Água, 2000; COUTO, R. C. Matarazzo: colosso brasileiro. São Paulo: Planeta, 2004. VAZ, M. L. A. Mulheres da elite cafeeira em São Paulo. Conciliação e resistência 1890/1930. Dissertação (Mestrado em História) — FFLCH, USP, São Paulo, 1995, mimeo.

${ }^{25}$ CANO, W. Raízes da concentração industrial em São Paulo. São Paulo: Difel, 1977 (Corpo e Alma do Brasil; v.LIII); BAER, W. A industrialização e o desenvolvimento econômico do 
Brasil. 4.ed. aumentada. (Trad. Paulo de Almeida Rodrigues). Rio de Janeiro: Fundação Getúlio Vargas, 1979; SILVA, S. Expansão cafeeira e origens da indústria no Brasil. São Paulo: Alfa-Ômega, 1976 (Biblioteca Alfa-Ômega de Ciências Sociais - Série 1aa: Economia; v.1); DEAN, W, A industrialização de São Paulo (1880-1945). 3.ed. São Paulo: Difel, s.d. (Corpo e Alma do Brasil); BALÁN, J. Migrações e desenvolvimento capitalista no Brasil: ensaios de interpretação histórico-comparativa. Estudos Cebrap, São Paulo, n.5, jul.-set. 1973; PRADO JUNIOR, C. História econômica do Brasil. 11.ed. São Paulo: Brasiliense, 1969. p.261-5.

${ }^{26}$ GIORGIANI, T. S. Pelos caminhos das palavras: uma breve interpretação da Rádio P.R.A.7 a partir das suas representações. Monografia (Conclusão de Curso) - Centro Universitário “Barão de Mauá”, Ribeirão Preto, 2005.

${ }^{27}$ A haussmanização - fenômeno urbano baseado na construção de imagens das reformas na capital francesa no século XIX - integrava uma série de intervenções cirúrgicas fruto da idéia de uma cidade doente - que se realizaria através da demolição do traçado arcaico e do tratamento disciplinador dado aos edifícios e jardins públicos. Sobre as concepções urbanísticas postas em práticas pelo Barão de Haussmann, ler: SALGUEIRO, H. A. Revisando Haussmann: os limites da comparação. A cidade, a arquitetura e os espaços verdes: o caso de Belo Horizonte. Revista USP, São Paulo, n.26, 1995, p.195-205. No que tange à realização de uma análise comparativa entre as concepções urbanas parisienses do século XIX e a recepção de suas idéias em importantes capitais nacionais no Brasil republicano - casos de Rio, Porto Alegre e Belo Horizonte — ver: PESAVENTO, S. J. O imaginário da cidade: visões literárias do urbano, Paris/Rio de Janeiro/Porto Alegre. Porto Alegre: Ed. UFRGS, 1999.

${ }^{28}$ NEEDELL, J. Belle Époque tropical: sociedade e cultura de elite no Rio de Janeiro na virada do século. (Trad. Celso Nogueira). São Paulo: Companhia das Letras, 1993; SEVCENKO, N. Literatura como missão: tensões sociais e criação cultural na Primeira República. 4.ed. São Paulo: Brasiliense, 1995. p.40; CHALHOUB, S. Cidade febril: cortiços e epidemias da corte imperial. São Paulo: Companhia das Letras, 1996.

${ }^{29}$ CAMPOS, C. M. Os rumos da cidade: urbanismo e modernização em São Paulo. São Paulo: Senac, 2002; SEVCENKO, N. Orfeu extático na metrópole: São Paulo, sociedade e cultura nos frementes anos 20. São Paulo: Companhia das Letras, 1992.

${ }^{30}$ SENNETT, R. Carne e pedra: o corpo e a cidade na civilização ocidental. (Trad. Marcos Aarão Reis). 2.ed. Rio de Janeiro: Record, 2001; ROSEN, G. Uma história da saúde pública. São Paulo: Ed. Unesp; Hucitec; Abrasco, 1994; LANNA, A. L. D. Uma cidade na transição: Santos, 1870-1913. São Paulo: Hucitec; Prefeitura Municipal de Santos/Secretaria da Cultura, 1996; HAHNER, J. Pobreza e política: os pobres urbanos no Brasil (1870-1920). Brasília: Ed. Unb, 1993.

${ }^{31}$ Cf. PAZIANI, R., 2004, op. cit. Ver também: VALADÃO, V. Memória arquitetônica em Ribeirão Preto. Dissertação (Mestrado em História) — FHDSS, Unesp, Franca, 1997.

${ }^{32}$ AZEVEDO, V. S. Entre a tela e a platéia: theatros e cinematographos na Franca da Belle Époque (1890-1930). Dissertação (Mestrado em História) — FHDSS, Unesp, Franca, 2001. 
${ }^{33}$ MARQUES, H. T. O aparentemente rural é urbano: o teatro e o cinema na modernização dos costumes em Mococa (1894-1925). Trabalho de Conclusão de Curso (Graduação em História) - Unesp/Fapesp, Franca, 2002; MARQUES, H. T. O teatro e a modernização dos costumes em Mococa (1894-1918). Ensaios de História, Franca (SP): Faculdade de História, Direito e Serviço Social/Unesp, v.7, n.1-2, p.11-32, 2002.

${ }^{34}$ FABRIS, A. (Org.) Ecletismo na arquitetura brasileira. São Paulo: Nobel; Edusp, 1987.

${ }^{35}$ Cf. DOIN, J. E. M., 2001, op. cit.

${ }^{36}$ ELIAS, N. O processo civilizador: uma história de costumes e formação do Estado e civilização. v.1. (Trad. Ruy Jungmann). 2.ed. Rio de Janeiro: Jorge Zahar, 1993.

${ }^{37}$ PEREIRA, R. M., 1998, op. cit.

${ }^{38}$ Nesse instante, a visão que já ocupava a posição de 'forma privilegiada do saber', havia se tornado um objeto do conhecimento e o sujeito passava, portanto, a 'experimentar' o mundo e a vasta proliferação de signos e imagens igualmente móveis e permutáveis. Instaurada na Europa, por volta do século XIX, essa mudança foi operada no Brasil quase um século depois, isto é, por volta de 1900, quando, em meio a intensas e rápidas mudanças promovidas ao toque da industrialização, da urbanização e da expansão dos meios de comunicação, houve um "salto direto de uma população majoritariamente analfabeta no início do século para uma ordem cultural centrada nos estímulos sensoriais das imagens e dos sons tecnicamente ampliados". Com a invenção da fotografia, por exemplo, cria-se no século XIX um "sistema irredutivelmente heterogêneo de relações discursivas, sociais, tecnológicas e institucionais", agrupados no que podemos considerar por 'efeitos da modernização’ que operou com a decodificação e desterritorialização da visão, deixando o observador de ser identificável segundo o estudo de pinturas ou gravuras para ser captado em discursos e práticas um pouco mais nebulosos, cujo imenso legado vão ser as indústrias da imagem e do espetáculo do século XX. CRARY, J. Techniques of the observer: on vision and modernity in the nineteenth century. Cambridge (Mass.): MIT Press, 1995. p.69; CRARY, J. Moderning vision. In: FOSTER, H. (Org.) Vision and visuality. Seattle: Bay Press, 1988. Ver também: SEVCENKO, 2001, op. cit., p.38.

39 “'Por 'tradição inventada', entende-se um conjunto de práticas, normalmente reguladas por regras tácita ou abertamente aceitas; tais práticas, de natureza ritual ou simbólica, visam inculcar certos valores e normas de comportamento através da repetição, o que implica, automaticamente, uma continuidade em relação ao passado...”. HOBSBAWM, E.; RANGER, T (Org.) A invenção das tradições. (Trad. Celina Cardim Cavalcante). 2.ed. Rio de Janeiro: Paz e Terra, 1997. p.9.

${ }^{40}$ Neste caso, Persona é utilizada no sentido maussiano, em que o indivíduo se dilui e se esfuma no desempenho de múltiplos papéis sociais. Veja-se MAUSS, M., Sociologia e antropologia. São Paulo: Ed. Pedagógica e Universitária; Edusp, 1974. v.I, p.225-31.

${ }^{41}$ BERMAN, M., 1997, op. cit.

${ }^{42}$ Neste sentido, destacam-se como estudos que se empenharam em interpretar o lugar das populações marginalizadas no espaço urbano: HAHNER, J. Pobreza e política..., op. cit.; 
DIAS, M. O. L. S. Cotidiano e poder em São Paulo no século XIX - Ana Gertrudes de Jesus. São Paulo: Brasiliense, 1984; FAUSTO, B. Crime e cotidiano: criminalidade em São Paulo (1880/1924). São Paulo: Brasiliense, 1984; CHALHOUB, S. Trabalho, lar e botequim: o cotidiano dos trabalhadores no Rio de Janeiro da Belle Époque. São Paulo: Brasiliense, 1986; SOIHET, R. Condição feminina e forma de violência: mulheres pobres e ordem urbana (1890-1920). Rio de Janeiro: Forense Universitária, 1989; MARTINS, J. S. Subúrbio: vida cotidiana e história no subúrbio de São Paulo. São Paulo: Hucitec, 1992. v.1; CARVALHO, J. M. Os bestializados: Rio de Janeiro e a república que não foi. São Paulo: Companhia das Letras, 1987.

${ }^{43}$ Sobre esse assunto, consultar: OLIVEIRA, L. L. A questão nacional na Primeira República. São Paulo: Brasiliense, 1990; OLIVEIRA, L. L. Americanos: representações da identidade nacional no Brasil e nos EUA. Belo Horizonte: UFMG, 2000. O advento da influência norte-americana poderia representar um marco limite para os estudos dos integrantes do Cemumc. Contudo, cabe lembrar que as pesquisas desse grupo estão baseadas numa compreensão mais dilatada do tempo, entendido aqui segundo a noção de tempo social. Tal perspectiva nos impele a constatar que as transformações históricas (menos ainda aquelas associadas à esfera do cultural) não se operam da noite para o dia, o que significa reconhecer que a influência francesa no Brasil caipira ainda se arrastou para além da Primeira Guerra Mundial, convivendo, a partir de então, com a influência norte-americana. Somente após a tomada do poder por Getúlio Vargas, em 1930, é que a influência francesa realmente se dissipa de forma crônica, posta a associação existente entre ela e a elite cafeeira paulista, grupo combatido por esse governante.

${ }^{44}$ Com a enxurrada de importações, o dólar sobe às alturas, passando de $3 \$ 000$ para $7 \$ 000$ em curto período. No final dos 30, a transição do fluxo de trocas entre o Brasil e a GrãBretanha como nosso principal parceiro para as transações cada vez mais vultosas com os norte-americanos já havia se consumado. Os Estados Unidos já compravam mais da metade da exportação brasileira, que entrava no território de Tio Sam livre de gravames, ao contrário do que ocorria com o mercado importador inglês, que despencara para um modesto sétimo lugar entre nossos importadores. RODRIGUES, J. H. O movimento rebelde de 1930 - a situação econômica, social e política. Carta Mensal, Órgão do Conselho Técnico da Confederação Nacional do Comércio. Rio de Janeiro, ano XVII, n.317, ago. 1981, p.12-4.

${ }^{45}$ FEBVRE, L. Por uma história dirigida - as investigações colectivas e o futuro da história. In: Combates pela História. (Trad. Leonor Martinho Simões e Gisela Moniz). 3.ed. Lisboa: Ed. Presença, 1989. p.61-9.

${ }^{46}$ Numa carta escrita em 1933, sob o impacto da física quântica, Lucien Febvre afirmava a necessidade de "Quebrar os quadros abstractos, ir direto aos problemas que o homem não especializado traz consigo, põe a si próprio e aos outros, fora de qualquer preocupação de escola, de qualquer 'espírito de botão"', atitude necessária e bem-vinda, posto que "tornarse-á sensível a todos a unidade do espírito humano, a unidade da inquietação humana perante o desconhecido...". FEBVRE, L. Contra o espírito de especialidade, 1989, op. cit., p.107-10. 
${ }^{47}$ Ibidem, p.65-6.

${ }^{48}$ BLOCH, M., 1941, op. cit.

${ }^{40}$ Ibidem, p.64.

${ }^{50}$ Cf. BURKE, M. L. G. P. As muitas faces da história - nove entrevistas. São Paulo: Ed. Unesp, 2000.

${ }^{51}$ BURKE, P. História e teoria social. São Paulo: Ed. Unesp, 2002. p.60-6.

${ }^{52}$ A trajetória dos historiadores italianos associados à proposta da micro-história pode ser conferida em: LIMA, H. E. A micro-história italiana. Rio de Janeiro: Record, 2006.

${ }^{53}$ DOSSE, F. A história em migalhas: dos Annales à nova história. Campinas (SP): Ed. Unicamp; São Paulo: Ensaio, 1994.

${ }^{54}$ VAINFAS, R. Micro-história: os protagonistas anônimos da história. Rio de Janeiro: Campus, 2002.

${ }^{55}$ AMADO, J. História e região: reconhecendo e construindo espaços. In: SILVA, Marcos. A República em migalhas: história regional e local. São Paulo: Marco Zero, 1990. p.7-11.

${ }^{56}$ ROSENTAL, P. A. Fredrik Barth e a microstoria. In: REVEL, J. (Org.) Jogos de escala - a experiências de microanálise. (Trad. Dora Rocha). Rio de Janeiro: Fundação Getúlio Vargas, 1998. p.151-72.

${ }^{57}$ LEVI, G. Sobre a micro-história. In: BURKE, P. (Org.) A escrita da história: novas perspectivas. (Trad. Magda Lopes). 4.reimpr. São Paulo: Ed. Unesp, 1992. p.133-62.

${ }^{58}$ REVEL, J. Micro-análise e construção do social. In: REVEL, J. (Org.), 1998, op. cit., p.26-8.

${ }^{59}$ BURKE, P., 2002, op. cit., p.83-6.

${ }^{60}$ BURKE, P. Abertura: a nova história, seu passado e seu futuro. In: BURKE, P. (Org.), 1992, op. cit., p.25.

${ }^{61}$ BLOCH, M., 1941, op. cit., p.61-2.

${ }^{62}$ HUNT, L. A nova história cultural. (Trad. Jefferson Luiz Camargo). São Paulo: Martins Fontes, 1992.p.14.

${ }^{63}$ LEVI, G., 1992, op. cit., p.133.

${ }^{64}$ BALANDIER, G. O contorno: poder e modernidade. (Trad. Suzana Martins). Rio de Janeiro: Bertrand Brasil, 1997.

${ }^{65}$ GIDDENS, A. As conseqüências da modernidade. (Trad. Raul Fiker). São Paulo: Ed. Unesp, 1991.

${ }^{66}$ HARVEY, D. A condição pós-moderna: uma pesquisa sobre as origens da mudança cultural. (Trad. Adail Ubirajara Sobral e Maria Stela Gonçalves). 7.ed. São Paulo: Loyola, 1998.

${ }^{67}$ ANDERSON, P. Modernidade e revolução. Novos Estudos Cebrap, São Paulo, n.14, 1986.

${ }^{68}$ RAMINELLI, R. História urbana. In: CARDOSO, C. F.; VAINFAS, R. (Org.) Domínios da História: ensaios de teoria e metodologia da história. Rio de Janeiro: Campus, 1997. p.185-202. 
${ }^{69}$ SARLO, B. Esquecer Benjamin. In: Paisagens imaginárias. (Trad. Rubia Prates e Sérgio Molina). São Paulo: Edusp, 1997. p.103-4.

${ }^{70}$ CALVINO, I. Cidades invisíveis. (Trad. Diogo Mainardi). São Paulo: Companhia das Letras, 1999.

${ }^{71}$ BRESCIANI, M. S. (Org.) Imagens da cidade: séculos XIX e XX. São Paulo: Marco Zero/Anpuh, 1994; PECHMAN, R. M. (Org.) Olhares sobre a cidade. Rio de Janeiro: Ed. UFRJ, 1994; DONNE, M. D. Teorias sobre a cidade. São Paulo: Martins Fontes, 1983.

${ }^{72}$ GARCIA CANCLINI, N. Culturas híbridas: estratégias para entrar e sair da modernidade. (Trad. Ana Regina Lessa e Heloísa Pezza Cintrão). São Paulo: Edusp, 1998. p.21.

${ }^{73}$ É curioso observar que tais negociações eram organizadas por integrantes administrativos do próprio Estado Brasileiro ou, quando não, pelos seus mais representativos empresários e homens de negócio, o que nos faz reconhecer a partir dessa esfera, mais uma vez, a imbricada relação entre interesses públicos e privados. São múltiplos os exemplos que se podem apontar nessa direção: desde os longínquos e corruptos Ministros Plenipotenciários da negociação do Empréstimo da Independência de 1824-1825, o Marquês de Barbacena e o Visconde de Itabaiana, passando pelo finório Barão de Penedo - ministro brasileiro em Londres, que quase nunca saía de Paris e mal falava português — , pelo Visconde de Mauá, pelo Barão de Souza Queiroz e, já no período republicano, por Rui Barbosa, Joaquim Murtinho, Campos Sales, Barão do Rio Branco, Pandiá Calógeras, Epitácio Pessoa, pela família Prado, pelos Guinle, por Cincinato Braga, Leopoldo de Bulhões etc. Veja-se DOIN, J. E. M. A dívida externa no Império: gênese do Estado Nacional e a modernização dos instrumentos de exploração - contribuição para o estudo da História Econômica e Financeira do Brasil (1824-1864). Tese (Doutorado em História Econômica) — FFLCH, USP, São Paulo, 1986.

${ }^{74}$ Se nos dedicarmos ao estudo dos empréstimos externos contraídos pelo Brasil durante o período estipulado (1852-1930), constataremos, mais do que nunca, as relações internacionais entre Brasil e Grã-Bretanha. Para além da Inglesa (como ficou conhecida a ferrovia que acessava o porto de Santos), outros tantos investimentos foram realizados no Brasil por homens de grandes fortunas e visão larga oriundos da Grã-Bretanha, até pelo menos a Grande Depressão de 1929. Em boa medida, isso se deu em virtude do novo papel exercido pelo Brasil no contexto do capitalismo mundial, por conta das oportunidades geradas pelo setor agro-exportador cafeeiro, e mediante a expansão econômica britânica, que se beneficiava do pioneirismo da 'sua revolução' e, especialmente por conta disso, exercia virtualmente um 'monopólio’ em determinados setores. Ibidem.

${ }^{75} \mathrm{O}$ conceito de civilização e a abordagem que procura entender as trocas entre civilizações díspares se apóiam, neste caso, especialmente, em: Cf. BRAUDEL, F. Civilização material, economia e capitalismo: séculos XV-XVIII — as estruturas do cotidiano. (Trad. Telma Costa). São Paulo: Martins Fontes, 1996.

${ }^{76}$ A respeito do papel dos imigrantes nas atividades urbanas ver: DI GIANNI, T. P. Italianos em Franca: imigrantes de boa estrela em uma cidade do interior. Franca: FHDSS/Unesp; Amazonas Prod. Calçados S.A., 1997; SILVA, H. M. M. O imigrante na urbanização cafeeira 
de São José do Rio Preto (1912-1940). Dissertação (Mestrado em História) - FHDSS, Unesp, Franca, 2002; TRUZZI, O. De mascates a doutores: sírio-libaneses em São Paulo. São Paulo: Sumaré; Fapesp; Brasília: CNPq, 1991.

${ }^{77}$ LE GOFF, J. História e memória. (Trad. Suzana Ferreira Borges). Campinas (SP): Ed. Unicamp, 1990; POLLAK, M. Memória, esquecimento e silêncio. Estudos históricos, Rio de Janeiro, n.3, 1989, p.3-15; POLLAK, M. Memória e identidade social. Estudos históricos, Rio de Janeiro, n.10, 1992, p.200-15.

${ }^{78}$ THOMPSON, E. P. A formação da classe operaria inglesa. (Trad. Denise Bottmann). Rio de Janeiro: Paz e Terra, 1987. p.9.

${ }^{79}$ HALBWACHS, M. A memória coletiva. (Trad. Laurent Leon Schaffter). São Paulo: Vértice, 1990.

${ }^{80}$ BARTLETT, F. C. Rememberig: a study in experimental and social psychology. Cambridge: Cambridge University Press, 1977.

${ }^{81}$ POLLAK, M., 1992, op. cit.

${ }^{82}$ Cf. BENJAMIN, W. Magia e técnica, arte e política. (Trad. Sergio Paulo Rouanet). São Paulo: Brasiliense, 1986. (Obras escolhidas, v.I).

${ }^{83}$ Embora as reflexões para o estudo da articulação entre economia, cotidiano e sociedade desenvolvidas por Marcel Mauss nas primeiras décadas do século XX fossem inovadoras, pouca atenção foi dada a esse assunto. A única exceção a essa regra diz respeito aos estudos promovidos por Karl Polanyi, ao longo da década de 1950. No decorrer da década de 1970, antropólogos como Mary Douglas, Louis Dumont e Marshal Sahlins se voltaram para a questão, produzindo estudos fecundos que vieram influenciar vários pesquisadores das ciências humanas. BEVILAQUA, C. B. Antropologia e História no mercado de consumo. In: SCWARCZ, L; GOMES, N. L. Antropologia e História: debate em região de fronteira. Belo Horizonte: Autêntica, 2000. p.71-92.

${ }^{84}$ Cf. BRAUDEL, F., 1996, op. cit.

${ }^{85}$ DE CERTEAU, M. A invenção do cotidiano (v.1): Artes de fazer. (Trad. Ephraim E. Alves e Lúcia E. Orth). Petrópolis (RJ): Vozes, 1997.

${ }^{86}$ MAFFESOLI, M. A conquista do presente: por uma sociologia da vida cotidiana. (Trad. Alípio de Souza Filho). 2.ed. Natal: Argos, 2001.

${ }^{87}$ BOURDIEU, P. A gênese dos conceitos de habitus e de campo. In: O poder simbólico. (Trad. Fernando Tomaz). Rio de Janeiro: Bertrand-Brasil, 1989. p.107-32. 